OSEANOLOGI DAN LIMNOLOGI DI INDONESIA

Online ISSN: $2477-328 \mathrm{X}$

Akreditasi RISTEKDIKTI No. 200/M/KPT/2020

http://oldi.lipi.go.id

\title{
Pengaruh Nitrat terhadap Biokorosi Logam oleh Konsorsium Bakteri Pereduksi Sulfat dari PLTA Saguling
}

\author{
Nur Fitriah Afianti ${ }^{12^{*}}$ dan Dea Indriani Astuti ${ }^{2}$ \\ ${ }^{1}$ Pusat Penelitian Oseanografi, Lembaga Ilmu Pengetahuan Indonesia \\ Jl. Pasir Putih 1, Ancol Timur, Jakarta, Indonesia \\ ${ }^{2}$ Sekolah Ilmu dan Teknologi Hayati, Institut Teknologi Bandung \\ Jl. Ganesa 10, Bandung, Indonesia \\ *Email: nurfitriahafianti@gmail.com
}

Submitted 29 December 2020. Reviewed 24 February 2021. Accepted 1 April 2021.

DOI: 10.14203/oldi.2021.v6i2.345

\begin{abstract}
Abstrak
Biokorosi merupakan korosi yang difasilitasi dan dipercepat oleh kehadiran mikroorganisme. Bakteri pereduksi sulfat (SRB) merupakan bakteri yang diketahui memiliki peran dalam menyebabkan biokorosi pada kondisi anaerob dengan menggunakan sulfat sebagai akseptor elektron terakhir. Biokorosi menyebabkan berkurangnya umur pemakaian dan meningkatkan biaya pemeliharaan dalam industri. Pada sistem pendingin di PLTA Saguling, korosi umumnya disebabkan oleh penggunaan air waduk yang tercemar oleh limbah organik dan anorganik, terutama sulfat. Pada penelitian ini telah dilakukan isolasi konsorsium bakteri pereduksi sulfat dari biofilm pada sistem pendingin generator di PLTA Saguling. Analisis molekuler menggunakan metode PCR-DGGE dengan penanda molekuler gen $d s r B(350 \mathrm{pb})$ menunjukkan konsorsium bakteri pereduksi sulfat mengandung 12 pita DNA yang diasumsikan sebagai spesies bakteri pereduksi sulfat yang berbeda. Konsorsium bakteri pereduksi sulfat diuji aktivitas biokorosinya terhadap logam ST37 (baja karbon) dan SUS304L (baja tahan karat) serta diberi perlakuan dengan variasi konsentrasi nitrat untuk mengetahui pengaruhnya terhadap aktivitas bakteri pereduksi sulfat. Konsorsium bakteri pereduksi sulfat menyebabkan korosi lebih tinggi pada logam ST37 dibandingkan SUS304L dengan laju korosi masingmasing adalah $0,07660 \mathrm{~mm} /$ tahun dan $0,00265 \mathrm{~mm} /$ tahun. Penggunaan nitrat $10 \mathrm{mM}$ efektif menghambat laju korosi logam ST37 dan menyebabkan perubahan komunitas bakteri pereduksi sulfat dengan hilangnya 6 pita DNA pada profil DGGE.
\end{abstract}

Kata kunci: biokorosi, nitrat, bakteri pereduksi sulfat, PLTA Saguling, logam

\begin{abstract}
The Influence of Nitrate in Metal Biocorrosion caused by Sulfate Reducing Bacteria from Saguling Hydropower. The corrosion facilitated and accelerated by the activities of microorganism is called biocorrosion. Sulfate reducing bacteria (SRB) is known as the bacteria that cause biocorrosion in anaerobic condition by using sulfate as the final electron acceptor. Biocorrosion reduces equipment lifetime and increases maintenance cost in industry. In the cooling system in Saguling hydropower, corrosion was commonly caused by utilization of contaminated water due to anorganic and organic waste, especially sulfate. In this research, sulfate reducing bacteria was isolated from biofilms in the cooling system of Saguling Hydropower. Molecular analysis using PCR-DGGE method with dsrB gene (350 bp) as molecular markers showed that SRB consortium contained 12 bands and assumed as different species of SRB. SRB consortium was tested to determine its biocorrosion activity over metal material of ST37 (carbon steel) and
\end{abstract}


SUS304 (stainless steel). The consortium then treated with 7 different nitrate concentrations to determine its effect against the sulfate reducing bacteria activity. SRB consortium caused higher corrosion to ST37 than SUS304L, with the corrosion rate of $0.07660 \mathrm{~mm} /$ year and $0.00265 \mathrm{~mm} / \mathrm{year}$, respectively. Concentration of $10 \mathrm{mM}$ nitrate effectively inhibited corrosion rate on ST37 and caused the changes in sulfate reducing bacteria communities, indicated by the disappearance of 6 bands in DGGE profile.

Keywords: biocorrosion, nitrate, sulfate reducing bacteria, Saguling hydropower, metal

\section{Pendahuluan}

Korosi merupakan penurunan kualitas material logam akibat interaksi dengan lingkungan. Korosi tidak dapat dicegah karena bersifat alami dan terjadi dengan sendirinya. Kerusakan material logam akibat korosi dapat difasilitasi dan dipercepat oleh kehadiran mikroorganisme, disebut sebagai biokorosi atau Microbiologically Influenced Corrosion (MIC) (Little \& Lee, 2014). Material logam yang mengalami biokorosi umumnya terjadi pada daerah yang memiliki kontak langsung dengan aktivitas mikroorganisme, seperti tempat distribusi air, pipa minyak, dan pipa gas alam. Dewasa ini, diketahui bahwa korosi yang difasilitasi oleh mikroorganisme menyebabkan kerusakan yang jauh lebih besar dibandingkan dengan korosi yang disebabkan oleh abrasi, elektrokimia maupun zat kimia (Enning \& Garrelfs, 2014). Biokorosi menyumbang setidaknya $20 \%$ dari total korosi yang terjadi pada sistem industri (Machuca, 2019).

Bakteri pereduksi sulfat merupakan bakteri yang dikenal karena kemampuannya menggunakan senyawa sulfat sebagai akseptor elektron untuk mendegradasi senyawa organik dan mereduksinya menjadi sulfida. Senyawa sulfida yang dihasilkan oleh bakteri pereduksi sulfat bersifat sangat reaktif, korosif dan beracun. Kontak langsung antara air tercemar yang mengandung bakteri pereduksi sulfat dan pipa dapat meningkatkan potensi terjadinya biokorosi. Pada proses reduksi sulfat diikuti dengan lepasnya elektron dari logam sehingga Fe dalam bentuk logam akan teroksidasi menjadi ion $\mathrm{Fe}^{2+}$ dan bereaksi dengan sulfida membentuk senyawa $\mathrm{FeS}$ yang dikenal sebagai produk korosi. Lapisan besi sulfida yang terbentuk dapat menjadi sisi katoda yang mempermudah penarikan elektron dari sisi anoda sehingga besi yang terionisasi menjadi lebih banyak dan laju korosi meningkat (Enning \& Garrelfs, 2014; Venzlaff et al., 2013).

PLTA Saguling merupakan pembangkit listrik tenaga air yang memasok listrik bagi wilayah Jawa, Madura dan Bali dengan total listrik yang dihasilkan mencapai 2,5 milyar per hari. Sistem pengoperasian PLTA Saguling terbagi menjadi dua sistem utama, yaitu sistem utama turbin dan sistem pendingin (cooling system). Sistem pendingin banyak memanfaatkan peralatan yang terbuat dari logam stainless steel SUS304L. Logam ini adalah logam campuran besi yang ditambahkan $\pm 10,5 \%$ kromium untuk memberikan ketahanan terhadap korosi. Stainless steel memiliki kemampuan tahan karat karena adanya lapisan chromium-oxide yang terbentuk dengan sendirinya ketika stainless steel mengalami kontak dengan udara yang mengandung oksigen. Umur pemakaian stainless steel ini berkisar antara 10 sampai 15 tahun, namun kebocoran pipa di PLTA Saguling sering terjadi dalam rentang pemakaian 3 sampai 5 tahun. Ketidaksesuaian umur pemakaian logam diprediksi sebagai akibat pemanfaatan air waduk Saguling sebagai sumber tenaga penggerak generator. PLTA Saguling memanfaatkan keberadaan waduk Saguling yang terletak di daerah hulu sungai terpanjang di Jawa Barat, yaitu sungai Citarum. Daerah hulu sungai Citarum merupakan daerah industri dan pemukiman yang menyebabkan waduk Saguling banyak tercemar oleh adanya limbah organik dan anorganik (Garno, 2001; Putra \& Hasan, 2012). Kandungan senyawa organik dan anorganik pada air tercemar merupakan sumber nutrisi yang memungkinkan mikro organisme untuk tumbuh dengan baik. Salah satu hasil metabolisme dari bakteri yang tumbuh pada air tercemar adalah senyawa sulfida berupa $\mathrm{H}_{2} \mathrm{~S}$, yang menjadi salah satu indikator adanya pertumbuhan bakteri pereduksi sulfat. Sulfat merupakan anion non volatil dan senyawa kimia yang sangat stabil.Pada keadaan anaerob, keberadaan senyawa sulfat yang tinggi meningkatkan kemungkinan korosi oleh bakteri pereduksi sulfat (sulfate reducing bacteria-SRB). Pada air waduk Saguling tercium bau seperti telur busuk yang mengindikasikan adanya kandungan senyawa $\mathrm{H}_{2} \mathrm{~S}$ yang merupakan hasil metabolisme bakteri pereduksi sulfat. Komunitas bakteri pada air waduk disebutkan tidak berbeda signifikan dengan profil komunitas bakteri pada biofilm bakteri yang menempel pada pipa di PLTA Saguling (Rosada et al., 2014). Selanjutnya, Rosada et al. (2017) juga telah mengkultivasi bakteri dari biofilm pada pipa pendingin di PLTA 
Saguling, yang didominasi oleh bakteri gram negatif. Bakteri yang diisolasi diantaranya adalah 3 jenis bakteri pereduksi sulfat, yaitu Desulfobacterium sp. (API1), Desulfobulbuselongatus (API2) dan Desulfobacter sp. (API3).

Beberapa senyawa seperti glutaraldehid, kalium vanadat, dan formaldehid diketahui dapat berperan sebagai biosida terhadap bakteri pereduksi sulfat. Namun penggunaan biosida ini tidak hanya membunuh bakteri pereduksi sulfat saja, tetapi juga bakteri lainnya pada komunitas tersebut. Nitrat merupakan salah satu senyawa yang relatif aman terhadap lingkungan namun secara tidak langsung dapat menekan pertumbuhan bakteri pereduksi sulfat. Penggunaan nitrat mulai banyak diterapkan dalam mengatasi korosi di industri. Nitrat dapat menginduksi pertumbuhan bakteri pereduksi nitrat-pengoksidasi sulfida (NR-SOB). Bakteri NR-SOB menggunakan nitrat sebagai akseptor elektron dan mengubahnya menjadi nitrogen. Proses metabolisme NR-SOB menghasilkan senyawa intermediet nitrit yang menghambat proses reduksi sulfat menjadi sulfida yang dikatalis oleh enzim dissimilatory sulphite reductase (dsr) dari bakteri pereduksi sulfat (Greene et al., 2003).

Pada penelitian ini dilakukan isolasi bakteri pereduksi sulfat dari biofilm di PLTA Saguling, Jawa Barat. Konsorsium bakteri pereduksi sulfat diuji aktivitas biokorosinya terhadap logam ST37 dan SUS304L serta diberi perlakukan dengan variasi konsentrasi nitrat untuk mengetahui pengaruh dan konsentrasi minimumnya dalam menghambat aktivitas bakteri pereduksi sulfat. Analisis komunitas konsorsium bakteri pereduksi sulfat juga dilakukan dengan metode denaturing gradient gel electrophoresis (DGGE) menggunakan fragmen gen $d s r B$ sebagai penanda molekuler.

\section{Metodologi}

\section{Isolasi Konsorsium Bakteri Pereduksi Sulfat}

Sampel biofilm diambil dari sistem pendingin base 5 di PLTA Saguling pada bulan Maret 2014. Sampel biofilm disimpan rapat dalam tabung falcon steril berukuran $15 \mathrm{~mL}$, diberi gas nitrogen $\left(\mathrm{N}_{2}\right)$, dan disimpan di dalam cooler box. Isolasi bakteri pereduksi sulfat dilakukan secara anaerob dengan menggunakan medium API Sulfat (1 g ekstrak ragi; 0,1 g asam askorbat; 0,2 $\mathrm{g}$ $\begin{array}{lllll}\mathrm{MgSO}_{4} ; & 0,01 \quad \mathrm{~g} & \mathrm{~K}_{2} \mathrm{HPO}_{4} ; & 0,1 \quad \mathrm{~g}\end{array}$ $\left(\mathrm{NH}_{4}\right)_{2} \mathrm{Fe}\left(\mathrm{SO}_{4}\right)_{2} \cdot 6 \mathrm{H}_{2} \mathrm{O} ; 10 \mathrm{~g} \mathrm{NaCl} ; 4 \mathrm{~mL}$ sodium laktat 60\%). Sampel biofilm sebanyak $0,1 \mathrm{~g}$ diinokulasikan ke dalam $10 \mathrm{~mL}$ medium API
Sulfat. Gas nitrogen kemudian dialirkan untuk mengurangi konsentrasi oksigen. Pertumbuhan bakteri pereduksi sulfat ditandai dengan perubahan warna medium menjadi hitam. Penentuan umur inokulum untuk uji korosi didasarkan pada tercapainya jumlah bakteri $10^{6}$ $\mathrm{CFU} / \mathrm{mL}$. Berdasarkan pola pertumbuhan tersebut diperkirakan bahwa jumlah bakteri $10^{6} \mathrm{CFU} / \mathrm{mL}$ akan tercapai pada umur sekitar 36 jam. Umur inokulum ini juga masih berada pada rentang ratarata umur inokulum bakteri pereduksi sulfat, yaitu sekitar 24 sampai 48 jam. Selanjutnya, umur 36 jam digunakan sebagai umur inokulum bakteri pereduksi sulfat untuk simulasi uji biokorosi dan pengaruh nitrat.

\section{Simulasi Inhibisi Biokorosi dengan Nitrat}

Sampel logam yang digunakan untuk uji biokorosi adalah logam baja tahan karat (stainless steel) tipe SUS304L (71\% Fe; $18,5 \% \mathrm{Cr} ; 8 \% \mathrm{Ni}$; $1,3 \% \mathrm{Mn}$; dan $0,5 \% \mathrm{Si}$ ) dan baja karbon (carbon steel) tipe ST37 (98,7\% Fe; 0,147\% C; dan 0,8\% $\mathrm{Mn})$. Masing-masing logam dipotong dengan ukuran $2 \times 2 \mathrm{~cm}$ untuk analisis pengurangan massa logam dan ukuran $0,5 \times 0,5 \mathrm{~cm}$ untuk analisis SEM. Logam dipoles secara manual sampai mengkilat dengan menggunakan kertas amplas berukuran 80,100 , dan 120 secara bertahap untuk menghilangkan pengotor dan lapisan oksida. Berat awal logam ditimbang dan logam disterilisasi menggunakan autoklaf.

Media perendaman untuk uji biokorosi diambil dari air bocoran pada sistem pendingin di PLTA Saguling pada bulan Mei 2014. Kualitas air Saguling sebagai media perendaman dianalisis sesuai dengan Standard Methods for The Examination of Water and Wastewater (SMEWW) di Laboratorium Kualitas Air, Fakultas Teknik Sipil dan Lingkungan ITB. Parameter fisika dan kimia yang dianalisis adalah $\mathrm{pH}$, suhu, TDS, TSS, salinitas, DO, BOD, COD, nitrat, nitrit, besi, klorida, sulfat, sulfida, total $\mathrm{P}$ dan total N. Media perendaman disterilisasi dengan metode pasteurisasi $\left(70^{\circ} \mathrm{C} ; 30\right.$ menit).

Perlakuan uji biokorosi dilakukan dengan menggunakan tujuh variasi konsentrasi nitrat, kontrol positif, dan kontrol negatif dengan dua kali pengulangan. Logam steril dimasukkan ke dalam $50 \mathrm{~mL}$ media perendaman dalam botol vial $50 \mathrm{~mL}$. Sebanyak $10 \% \mathrm{v} / \mathrm{v}$ inokulum konsorsium SRB diinokulasi pada media.Variasi konsentrasi nitrat yang ditambahkan masing-masing adalah 1 $\mathrm{mM}, 5 \mathrm{mM}, 10 \mathrm{mM}, 20 \mathrm{mM}, 40 \mathrm{mM}, 60 \mathrm{mM}$ dan $80 \mathrm{mM}$. Botol vial ditutup dengan menggunakan tutup karet dan disuntikkan gas nitrogen untuk menciptakan kondisi anaerob. Inkubasi dilakukan selama 8 minggu pada suhu ruang. 


\section{Analisis Laju Korosi}

Penentuan laju korosi dilakukan berdasarkan hasil pengukuran pengurangan massa logam uji. Data dianalisis secara statistik menggunakan SPSS dengan metode ANOVA satu arah dan uji lanjutan Duncan untuk mengetahui pengaruh dan beda antar perlakuan. Logam yang telah mengalami perlakuan dibersihkan menggunakan ultrasonic cleaner (etanol 70\%) selama 1 menit untuk menghilangkan lemak yang menempel pada permukaan logam. Penimbangan massa akhir logam setelah perlakuan dilakukan menggunakan neraca analitik dengan galat $0,1 \mathrm{mg}$ kemudian dihitung selisihnya dengan massa logam sebelum perlakuan. Laju korosi dihitung menggunakan rumus berdasarkan ASTM (2011):

Keterangan:

$$
\text { LajuKorosi }(C R)=\frac{w \times K}{\rho \times A \times t}
$$

$C R=$ laju korosi (mm/tahun)

$w=$ pengurangan massa $(\mathrm{g})$

$K=$ konstanta $\left(8,76 \times 10^{4}\right)$

$\rho=$ massa jenis logam $\left(\mathrm{g} / \mathrm{cm}^{3}\right)$

$A=$ area yang terpapar $\left(\mathrm{cm}^{2}\right)$

$t=$ periode pemaparan $(\mathrm{jam})$

Pada permukaan logam uji dilakukan pengambilan citra tipe korosi dan biofilm yang terbentuk pada permukaan logam dengan menggunakan Scanning Electron Microscopy (SEM). Untuk pengambilan citra tipe korosi, lapisan lemak pada sampel logam dihilangkan menggunakan ultrasonic cleaner (etanol 70\%) selama 1 menit dan dikeringkan pada suhu ruang kemudian disimpan dalam plastik zip dengan tambahan silika gel. Untuk pengambilan citra biofilm, sampel logam direndam larutan 4\% formaldehid dan $1 \%$ glutaraldehid dalam PBS selama 12 jam. Selanjutnya sampel dikeringkan selama 12 jam di dalam desikator. Sebelum dilakukan pengamatan menggunakan SEM, sampel biofilm dilapisi emas atau platina. Analisis SEM dilakukan di Pusat Survei Geologi, Bandung.

\section{Analisis Komunitas Bakteri Pereduksi Sulfat}

Perubahan komunitas bakteri dianalisis dengan metode PCR-DGGE. Ekstraksi total DNA bakteri dilakukan dengan menggunakan metode modifikasi ekstraksi DNA dari tanah terkontaminasi limbah (Hinoue et al., 2004). Lisis sel dilakukan dengan menggunakan 3001 bufer lisis $(10 \mathrm{mM}$ tris-Cl, $100 \mathrm{mM} \mathrm{NaCl}, 1 \mathrm{mM}$ EDTA, $20 \mathrm{mg} / \mathrm{mL}$ lisozim) dan dibiarkan selama 10 menit pada suhu ruang, kemudian ditambahkan 51 proteinase $\mathrm{K}(11 \mathrm{mg} / \mathrm{mL})$ dan $50110 \%$ SDS.
Selanjutnya, diinkubasi pada $60^{\circ} \mathrm{C}$ selama 2 jam. Purifikasi DNA dari pengotor dilakukan dengan menggunakan 1 kali volume TE-saturated phenol dan 1 kali volume chloroform-isoamyl alcohol (CI). DNA diendapkan dengan 0,1 kali volume 3 $\mathrm{M}$ sodium asetat $\mathrm{pH} 5$ dan 2 kali volume etanol absolut pada $-80^{\circ} \mathrm{C}$ selama 10 menit. Pelet DNA dielusi dengan $50 \mu \mathrm{l}$ TE buffer dan disimpan pada suhu $-20^{\circ} \mathrm{C}$. Gen $d s r B$ yang berukuran sekitar 350 bp diamplifikasi menggunakan primer DSRp2060-GC (5'-GC clamp-CAA CAT CGT YCA YAC CCA GGG-3') dan primer DSR4R (5'-GTG TAG CAG TTA CCG CA-3') (Geets et al., 2006; Priha et al., 2013; Zhang et al., 2017). Proses PCR dilakukan dengan menggunakan KAPA 2G Fast Readymix dengan kondisi touchdown pada suhu annealing $65^{\circ} \mathrm{C}$ dan turun $0,5^{\circ} \mathrm{C}$ pada siklus berikutnya sebanyak 20 siklus, kemudian dilanjutkan dengan suhu annealing $55^{\circ} \mathrm{C}$ sebanyak 15 siklus. Analisis DGGE dari amplikon gen $d s r B$ dilakukan menggunakan DCode Universal Mutation Detection System (BIORAD).Konsentrasi gel poliakrilamid 6\% dan denaturan $60 \%$ sampai $70 \%$ digunakan untuk memisahkan pita DNA. Elektroforesis dilakukan selama 9 jam pada tegangan 100 volt dan suhu $60^{\circ} \mathrm{C}$. Gel poliakrilamida diwarnai menggunakan metodesilver staining(Creste et al., 2001).

\section{Enumerasi Bakteri Pereduksi Sulfat dan Pengukuran Kadar Sulfat}

Enumerasi bakteri pereduksi sulfat pada medium dilakukan selama 8 minggu dengan menggunakan metode total plate count. Sebanyak $1 \mathrm{~mL}$ sampel pada tiga tabung terakhir dari seri pengenceran sampel diinokulasi pada media API Sulfat agar dengan metode tuang dan double layer agar. Selanjutnya, media dilapisi parafin cair pada permukaan bagian atas medium dan dialirkan gas $\mathrm{N}_{2}$ untuk menciptakan kondisi anaerob. Setiap cawan petri dimasukkan ke dalam anaerobic jar dan diinkubasi pada suhu $30^{\circ} \mathrm{C}$. Koloni bakteri pereduksi sulfat akan menunjukkan koloni berwarna hitam. Pengukuran kadar sulfat dilakukan dengan menggunakan metode turbidimetri berdasarkan SNI 06-6989.20-2004. Sebanyak $10 \mathrm{~mL}$ larutan sampel ditambahkan 4 $\mathrm{mL}$ larutan buffer $\left(30 \mathrm{~g} \mathrm{MgCl}_{2} \cdot 6 \mathrm{H}_{2} \mathrm{O}, 5 \mathrm{~g}\right.$ $\mathrm{CH}_{3} \mathrm{COONa} .3 \mathrm{H}_{2} \mathrm{O}, 1 \mathrm{~g} \mathrm{KNO}_{3}$ dan $20 \mathrm{~mL}$ asam asetat, dalam $1000 \mathrm{~mL}$ air suling bebas sulfat). Campuran larutan dihomogenkan dengan menggunakan pengaduk magnet pada kecepatan tetap selama $(60 \pm 2)$ detik, sambil diaduk tambahkan 0,4 g sampai dengan 0,6 $\mathrm{g} \mathrm{BaCl}_{2}$. Selanjutnya, dilakukan pengukuran densitas dengan spektrofotometer pada panjang gelombang $420 \mathrm{~nm}$ setelah $(5 \pm 0,5)$ menit penambahan $\mathrm{BaCl}_{2}$. 
Hasil

\section{Konsorsium bakteri pereduksi sulfat}

Konsorsium bakteri dari biofilm yang menempel pada pipa sistem pendingin menunjukkan pertumbuhan bakteri pereduksi sulfat pada media API sulfat.Pertumbuhan tersebut ditandai dengan perubahan warna media menjadi hitam. Medium API Sulfat merupakan medium diferensial yang memberikan warna hitam (blackening) pada pertumbuhan bakteri pereduksi sulfat sebagai reaksi antara sulfida hasil metabolisme bakteri pereduksi sulfat dengan ion besi yang terdapat di dalam medium. Pertumbuhan bakteri yang ditandai oleh perubahan warna medium menjadi hitam (Gambar 1.a) ini terjadi setelah masa inkubasi selama 8 hari. Berdasarkan analisis gen $d s r B$ dengan metode PCR-DGGE, konsorsium bakteri pereduksi sulfat yang berhasil diisolasi mengandung 12 pita atau OTU (Gambar 1.b). Satu pita DNA pada profil DGGE diasumsikan mewakili satu jenis mikroorganisme.

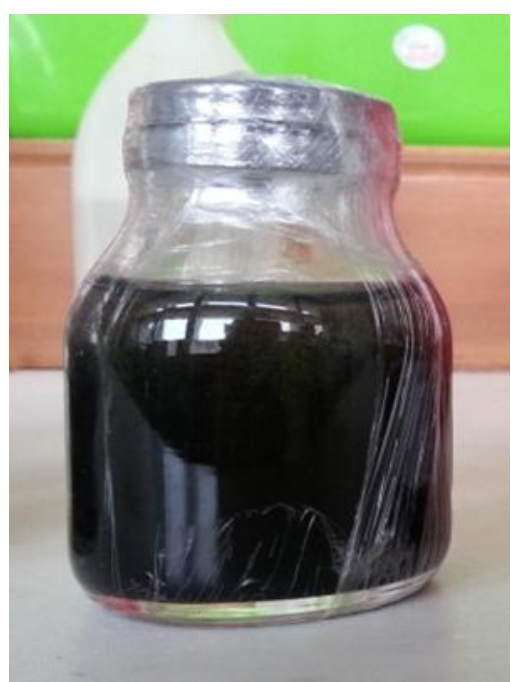

(a)

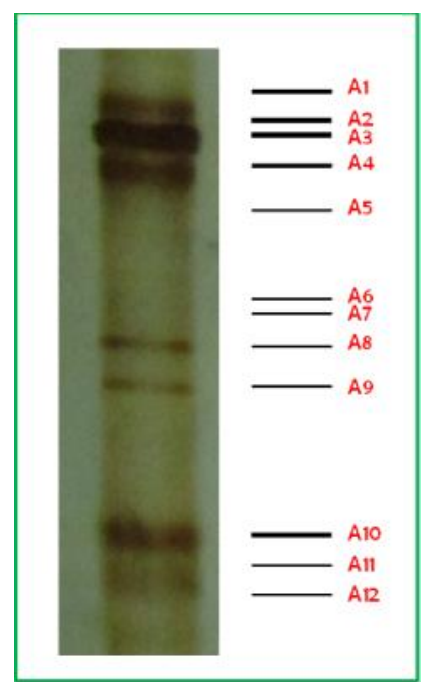

(b)

Gambar 1 Konsorsium bakteri pereduksi sulfat: (a) pertumbuhannya pada media API sulfat cair; dan (b) Profil DGGE berdasarkan gen $d s r B$ dengan konsentrasi gel poliakrilamid 6\% dan denaturan 50$70 \%$ pada 100V selama 9 jam, menunjukkan 12 OTU (A1-A12).

Figure 1. Sulfate reducing bacteria consortium: (a) growth on Sulfate API Broth; and (b) DGGE profile based on $d s r B$ gene using $6 \%$ polyacrylamide gel and $50-70 \%$ denaturant at $100 \mathrm{~V}$ for 9 hours, showed 12 OTU (A1-A12).

\section{Air waduk Saguling sebagai media perendaman}

Media perendaman untuk uji biokorosi merupakan air bocoran dari sistem pendingin PLTA Saguling. Air bocoran ini berasal dari air waduk Saguling yang dimanfaatkan dalam sistem penggerak turbin. Komposisi fisika kimia air waduk Saguling pada bulan Mei 2014 yang digunakan sebagai media perendaman untuk uji biokorosi ditunjukkan pada Tabel 1.Kondisi suhu dan $\mathrm{pH}$ berada pada rentang yang mendukung pertumbuhan bakteri yang baik. Nilai $\mathrm{pH}$ yang cocok untuk pertumbuhan bakteri yaitu sekitar 4 sampai 9, sedangkan pada bakteri pereduksi sulfat pertumbuhan optimumnya dicapai pada kisaran pH sekitar 7 dan mulai terhambat ketika $\mathrm{pH}$ kurang dari 5,5 atau lebih besar dari 9. Suhu optimum untuk pertumbuhan kultur murni bakteri pereduksi sulfat rata-rata antara $28^{\circ} \mathrm{C}$ sampai $32^{\circ} \mathrm{C}$. Hasil pengukuran juga menunjukkan kadar BOD dan COD yang cukup tinggi mengindikasikan kandungan senyawa organik sebagai sumber karbon untuk pertumbuhan bakteri. Selain itu, media perendaman mengandung ion sulfat yang cukup tinggi, yaitu $34,2 \mathrm{mg} / \mathrm{L}$. Bakteri pereduksi sulfat yang tumbuh secara anaerob membutuhkan ion sulfat sebagai akseptor elektron. 
Tabel 1 Parameter Fisika dan Kimia Air Pendingin PLTA Saguling

Table 1. Physical and Chemical Parameters of Saguling Water

\begin{tabular}{lcc}
\hline \multicolumn{1}{c}{ Parameters } & Unit & Value \\
\hline Temperature & ${ }^{\circ} \mathrm{C}$ & 27.7 \\
$\mathrm{pH}$ & - & 7.02 \\
$\mathrm{TDS}$ & $\mathrm{mg} / \mathrm{L}$ & 179 \\
$\mathrm{TSS}$ & $\mathrm{mg} / \mathrm{L}$ & 20 \\
Salinity & $\%$ & 0.1 \\
DO & $\mathrm{mg} / \mathrm{L}$ & 4.27 \\
BOD & $\mathrm{mg} / \mathrm{L}$ & 17.6 \\
$\mathrm{COD}$ & $\mathrm{mg} / \mathrm{L}$ & 30 \\
Nitrate $\left(\mathrm{NO}_{3}{ }^{-\mathrm{N}}\right)$ & $\mathrm{mg} / \mathrm{L}$ & 3.47 \\
Nitrite $\left(\mathrm{NO}_{2}-\mathrm{N}\right)$ & $\mathrm{mg} / \mathrm{L}$ & 0.023 \\
Iron $(\mathrm{Fe})$ & $\mathrm{mg} / \mathrm{L}$ & 0.256 \\
Chloride $\left(\mathrm{Cl}^{-}\right)$ & $\mathrm{mg} / \mathrm{L}$ & 17.8 \\
Sulfate $\left(\mathrm{SO}_{4}{ }^{2-}\right)$ & $\mathrm{mg} / \mathrm{L}$ & 34.2 \\
P Total & $\mathrm{mg} / \mathrm{L}$ & 0.288 \\
N Total & $\mathrm{mg} / \mathrm{L}$ & 2.77 \\
\hline
\end{tabular}

\section{Uji biokorosi}

Konsorsium bakteri pereduksi sulfat menyebabkan korosi lebih tinggi terhadap logam ST37 dibanding SUS304L dengan laju korosi masing-masing adalah $0,07660 \pm 0,00327$ $\mathrm{mm} / \mathrm{tahun}$ dan $0,00265 \pm 0,00432 \mathrm{~mm} / \mathrm{tahun}$ dengan perbedaan laju korosi yang sangat signifikan $(\mathrm{P}<0,05)$. Perlakuan tujuh variasi konsentrasi nitrat pada logam SUS304L yang diinokulasi bakteri pereduksi sulfat menunjukkan adanya penurunan laju korosi dibandingkan dengan kontrol yang hanya diinokulasikan SRB saja. Akan tetapi, penggunaan konsentrasi nitrat dengan ketujuh variasi tidak menunjukkan perbedaan yang signifikan. Selain itu, berdasarkan analisis ANOVA, penggunaan nitrat untuk menghambat aktivitas bakteri pereduksi sulfat tidak berpengaruh terhadap laju korosi logam tahan karat SUS304L karena memberikan hasil yang tidak berbedanyata $(\mathrm{P}>0,05)$ dengan perlakuan tanpa nitrat (Gambar 2.a).
Hasil uji pada logam baja karbon ST37 menunjukkan urutan laju korosi oleh perlakuan nitrat $1 \mathrm{mM}>5 \mathrm{mM}>10 \mathrm{mM}>40 \mathrm{mM}>20 \mathrm{mM}$ $>60 \mathrm{mM}>80 \mathrm{mM}$ dengan nilai laju korosi berturut-turut adalah $0,06200 \pm 0,00665 \mathrm{~mm} / \mathrm{tahun}$; $0,04068 \pm 0,00279 \mathrm{~mm} /$ tahun; $0,01550 \pm 0,00504$ $\mathrm{mm} /$ tahun; $\quad 0,01412 \pm 0,00294 \quad \mathrm{~mm} /$ tahun; $0,01135 \pm 0,00093 \mathrm{~mm} /$ tahun; $0,00996 \pm 0,00073$ $\mathrm{mm} /$ tahun dan $0,00747 \pm 0,00117 \mathrm{~mm} / \mathrm{tahun}$ (Gambar 2.b).Penggunaan nitrat $1 \mathrm{mM}$ dan $5 \mathrm{mM}$ tidak menyebabkan pengurangan logam yang signifikan dibanding kontrol yang hanya diinokulasikan SRB. Konsentrasi nitrat di atas 10 $\mathrm{mM}$ memberikan penurunan laju korosi logam ST37 yang signifikan. Namun, laju korosi antara perlakuan nitrat $10 \mathrm{mM}, 20 \mathrm{mM}, 40 \mathrm{mM}, 60 \mathrm{mM}$ dan $80 \mathrm{mM}$ tidak menunjukkan perbedaan yang nyata. Oleh karena itu, penggunaan nitrat dengan konsentrasi $10 \mathrm{mM}$ efektif untuk menurunkan laju korosi logam ST37. 
(a)

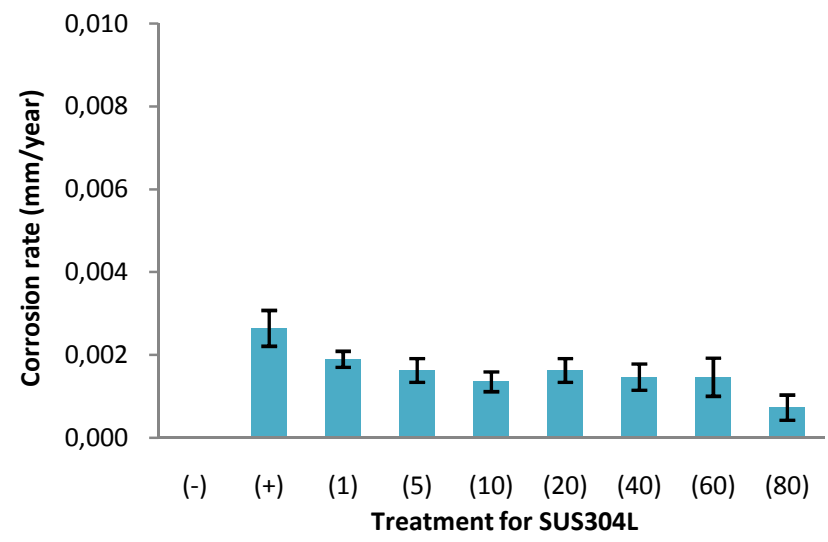

$(-)=$ without SRB consortium

$(+)=$ SRB consortium

(1) $=\mathrm{SRB}+1 \mathrm{mM} \mathrm{NaNO}$

(5) $=\mathrm{SRB}+5 \mathrm{mM} \mathrm{NaNO}_{3}$

$(10)=\mathrm{SRB}+10 \mathrm{mM} \mathrm{NaNO}$

(b)

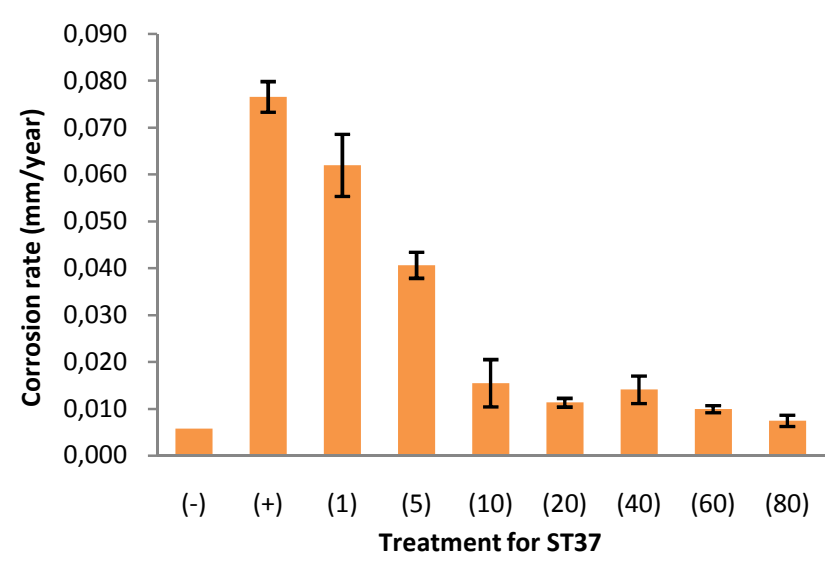

$(20)=\mathrm{SRB}+20 \mathrm{mM} \mathrm{NaNO}_{3}$

$(40)=\mathrm{SRB}+40 \mathrm{mM} \mathrm{NaNO}$

$(60)=\mathrm{SRB}+60 \mathrm{mM} \mathrm{NaNO}_{3}$

$(80)=\mathrm{SRB}+80 \mathrm{mM} \mathrm{NaNO}$

Gambar 2. Laju korosi pada logam: (a) SUS304L dan (b) ST37

Figure 2. Metal corrosion rate of: (a) SUS304L and (b) ST37

Berdasarkan analisis SEM, perlakuan korosi logam SUS304L oleh konsorsium bakteri pereduksi sulfat menunjukkan bahwa logam SUS304L tidak mengalami korosi dan bentuk permukaan logam tidak mengalami gangguan sama sekali (Gambar 3.a). Berdasarkan hasil pengurangan massa logam, uji biokorosi logam SUS304L oleh konsorsium SRB hanya dilakukan selama 8 minggu sehingga pengurangan massa yang terjadi relatif sangat kecil, yaitu 0,0012 gram. Visualisasi permukaan logam uji ST37 tanpa perlakuan nitrat menunjukkan adanya bentuk produk korosi seperti karang yang sulit untuk dibersihkan (Gambar 3.b), sehingga bentuk korosi sumuran akibat aktivitas bakteri pereduksi sulfat tidak dapat dilihat dengan jelas.Namun, apabila dibandingkan dengan logam ST37 dengan perlakuan SRB dan penambahan $10 \mathrm{mM}$ nitrat (Gambar 3.c), terlihat adanya perbedaan dari banyaknya produk korosi.Pada logam ST37 dengan perlakuan nitrat, permukaan logam uji lebih halus dan tidak terdapat banyak bentuk karang sebagai tanda adanya korosi.

Penampakan biofilm bakteri menunjukkan bahwa penggunaan $10 \mathrm{mM}$ nitrat memungkinkan terbentuknya biofilm bakteri pada permukaan logam (Gambar 4). Dari segi jumlah, dengan luas area yang sama menunjukkan bahwa jumlah bakteri pereduksi sulfat tanpa perlakuan nitrat lebih banyak dibandingkan bakteri pada perlakuan $10 \mathrm{mM}$ nitrat. Pada perlakuan nitrat, terlihat adanya bakteri yang berbentuk seperti spiral.Bakteri ini kemungkinan adalah bakteri pereduksi sulfat dari genus Desulfovibrio yang berbentuk spiral. Desulfovibrio vulgaris diketahui memiliki mekanisme pertahanan terhadap senyawa nitrit (Greene et al., 2003). 

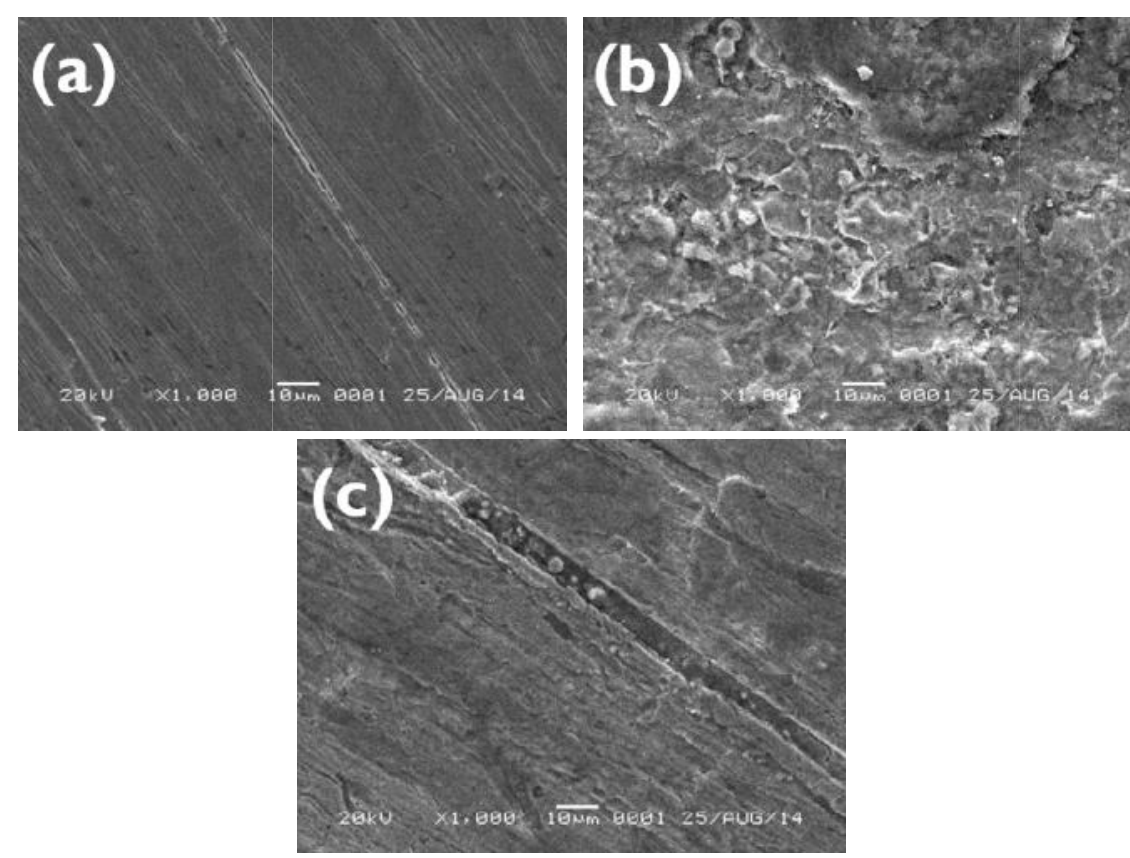

Gambar 3. Visualisasi permukaan logam menggunakan SEM setelah 8 minggu uji biokorosi: (a) Logam SUS304L (b) Logam ST37 (c) Logam ST37 dengan 10 mM nitrat.

Figure 3. Visualization of the metal surface using SEM after biocorrosion test for 8 weeks: (a) SUS304L coupon (b) ST37 coupon (c) ST37 coupon with $10 \mathrm{mM}$ nitrate.
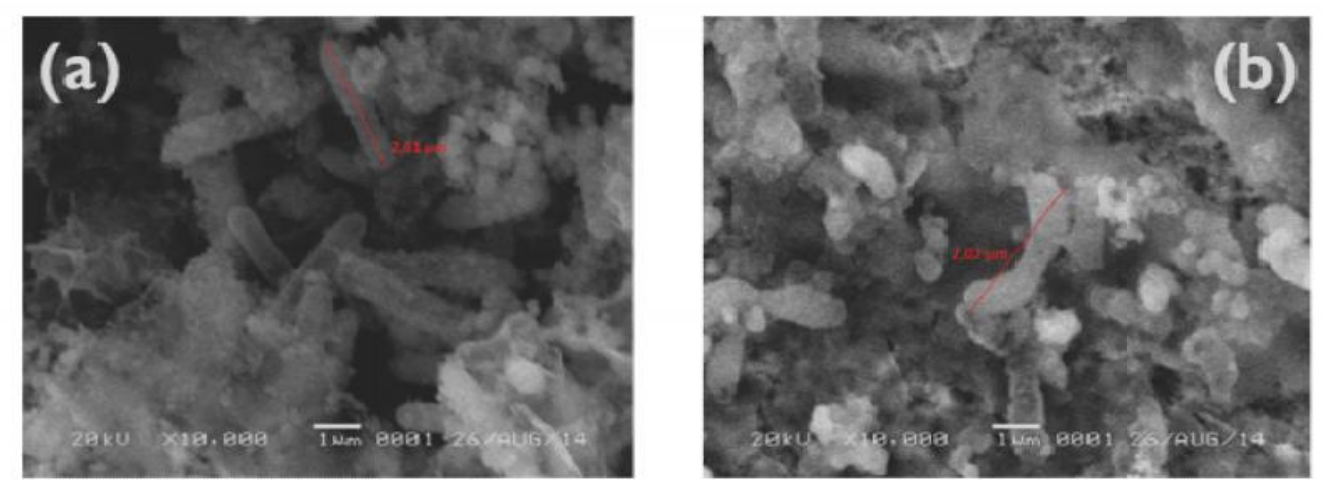

Gambar 4. Visualisasi biofilm setelah 8 minggu uji biokorosi pada permukaan: (a) Logam ST37 (b) Logam ST37 dengan $10 \mathrm{mM}$ nitrat.

Figure 4. Visualization of biofilm after 8 weeks of biocorrosion test on the surface of: (a) ST37 coupon (b) ST37 coupon with $10 \mathrm{mM}$ nitrate.

\section{Perubahan komunitas bakteri pereduksi sulfat \\ Analisis komunitas bakteri pereduksi sulfat dilakukan secara molekuler dengan menggunakan penanda molekur gen $d s r B$ menggunakan metode PCR-DGGE. Penggunaan metode molekuler lebih efektif dibandingkan metode konvensional yang memerlukan waktu lama untuk kultivasi dan sulitnya bakteri pereduksi sulfat dibedakan dalam bentuk koloni. Gambar 5 menunjukkan profil kemunculan bakteri pereduksi sulfat selama masa perlakuan uji biokorosi pada logam ST37. Logam dengan perlakuan nitrat memiliki jumlah OTU yang lebih sedikit dibandingkan tanpa nitrat.Pada setiap kolom dari sampel yang berbeda-beda, terdapat pita DNA yang selalu muncul dengan ketebalan yang berbeda-beda dari waktu ke}

waktu, yaitu pita DNA A3 dan A10. Perbedaan ketebalan ini menunjukkan tingginya jumlah kopi gen untuk bakteri yang mewakili pita tersebut dan dapat dikaitkan dengan dominansi spesies tersebut terhadap spesies lain dalam pencuplikan yang sama pada kolom tersebut (McCaig et al., 2001). Secara umum, perlakuan dengan nitrat menyebabkan perubahan komunitas pada konsorsium bakteri pereduksi sulfat, dengan hilangnya beberapa pita DNA pada profil DGGE, diantaranya pita A1, A5, A6, A7, A8 dan A9. Pita A6, A7, A8 dan A9, merupakan pita yang hilang seiring dengan semakin tingginya konsentrasi nitrat pada perlakuan. Oleh karena itu diasumsikan bahwa bakteri pereduksi sulfat yang diwakili oleh pita A6, A7, A8 dan A9 merupakan bakteri 
pereduksi sulfat yang terhambat oleh penambahan nitrat. Sedangkan bakteri pereduksi sulfat pada pita A1 dan A5 kemungkinan memiliki mekanisme untuk mengatasi inhibisi oleh nitrat, karena pita A1 dan A5 yang sempat hilang pada penggunaan nitrat dengan konsentrasi rendah, namun membentuk pita DNA pada konsentrasi nitrat 20 sampai $60 \mathrm{mM}$.

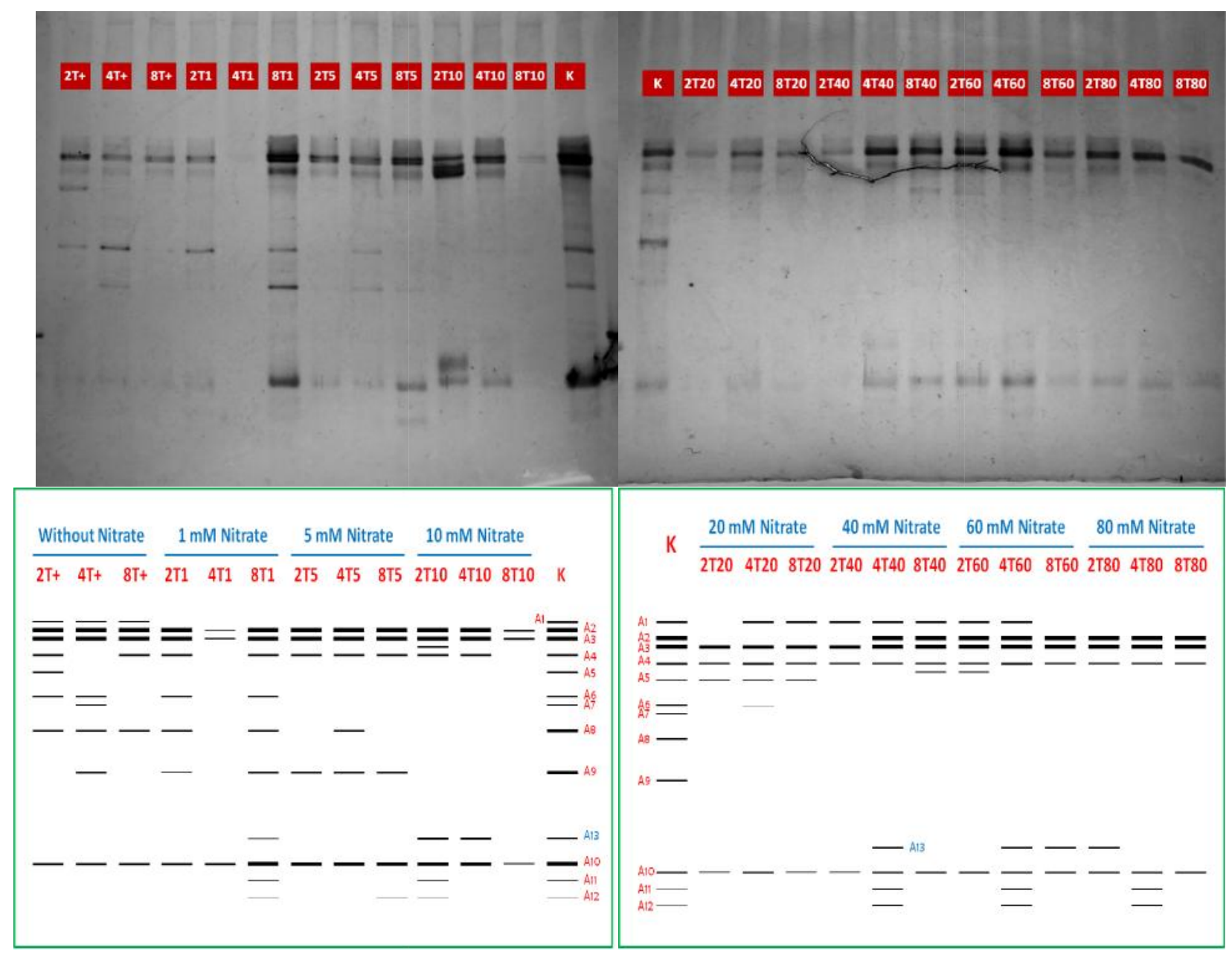

Note : $\mathrm{K}=$ the DGGE profile of a SRB consortium. Samples from the second weeks (2Txx), fourth week (4Txx) and eighth week (8Txx) with treatment without nitrate $(2 \mathrm{~T}+, 4 \mathrm{~T}+, 8 \mathrm{~T}+)$ and nitrate treatment (1 mM (2T1,4T1,8T1), $5 \mathrm{mM}(2 \mathrm{~T} 5,4 \mathrm{~T} 5,8 \mathrm{~T} 5), 10 \mathrm{mM}$ (2T10,4T10,8T10), $20 \mathrm{mM}$ (2T20,4T20,8T20), $40 \mathrm{mM} \quad(2 \mathrm{~T} 40,4 \mathrm{~T} 40,8 \mathrm{~T} 40), \quad 60 \mathrm{mM} \quad(2 \mathrm{~T} 60,4 \mathrm{~T} 60,8 \mathrm{~T} 60)$, and $80 \mathrm{mM}$ (2T80,4T80,8T80)).

Gambar 5. Profil DGGE bakteri pereduksi sulfat pada perlakuan logam ST37.

Figure 5. DGGE profile of sulfate reducing bacteria from biocorrosion test of ST37 coupon.

\section{Pola Perubahan Jumlah Bakteri pada Media Perendaman}

Perlakuan penambahan nitrat pada uji biokorosi logam ST37 menyebabkan penurunan jumlah sel bakteri pereduksi sulfat (Gambar 6.a). Pertumbuhan bakteri pereduksi sulfat ditandai dengan penurunan konsentrasi sulfat yang dimanfaatkan untuk metabolism bakteri.Perlakuan penambahan nitrat pada uji biokorosi terhadap logam ST37 menyebabkan perubahan jumlah bakteri pereduksi sulfat yang fluktuatif namun memiliki kecenderungan penurunan jumlah bakteri selama masa perlakuan 8 minggu. Penambahan konsentrasi nitrat 1 dan $5 \mathrm{mM}$ tidak menekan pertumbuhan bakteri pereduksi sulfat pada logam ST37 secara signifikan. Konsentrasi nitrat $20 \mathrm{mM}$ atau lebih mampu menekan jumlah bakteri sejak minggu pertama hingga akhir perlakuan sedangkan konsentrasi $10 \mathrm{mM}$ terjadi pada minggu kedua. Penurunan jumlah bakteri diikuti oleh tren kenaikan $\mathrm{pH}$ medium dan dilanjutkan tren penurunan $\mathrm{pH}$ di akhir masa perlakuan (Gambar 6.b). Sedangkan pada kontrol yang hanya diinokulasikan konsorsium bakteri pendegradasi sulfat tanpa penambahan nitrat, mengalami tren penurunan $\mathrm{pH}$ sejak awal perlakuan. Penambahan nitrat menyebabkan fluktuasi kadar sulfat, sedangkan kontrol korosi SRB tanpa penambahan nitrat mengalami penurunan kadar sulfat selama perlakuan (Gambar 6.c). 
(a)

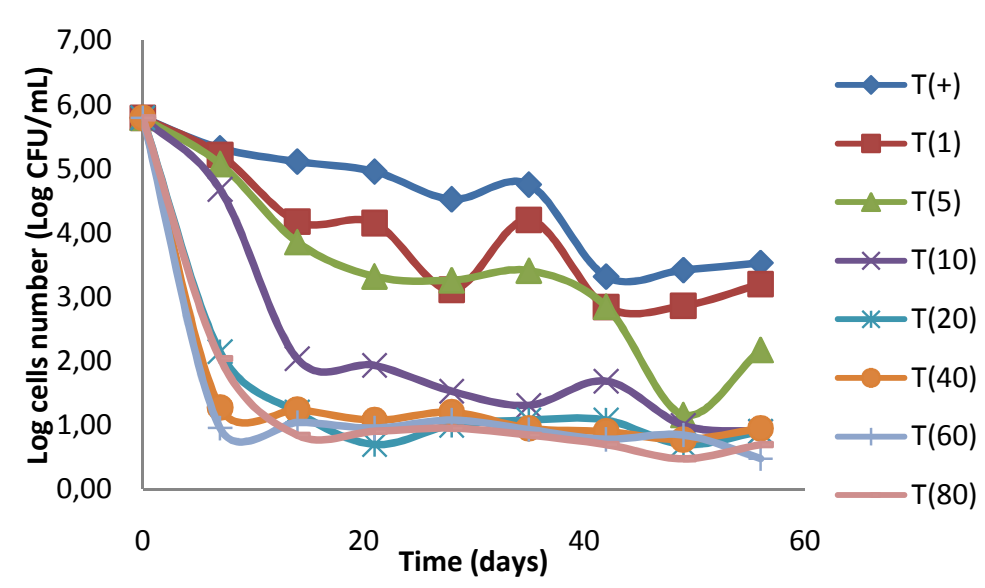

(b)

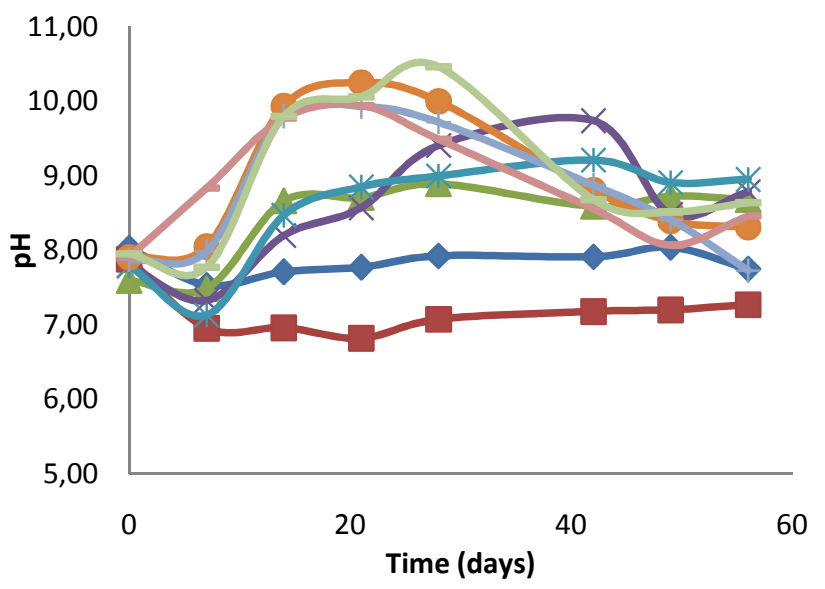

(c)

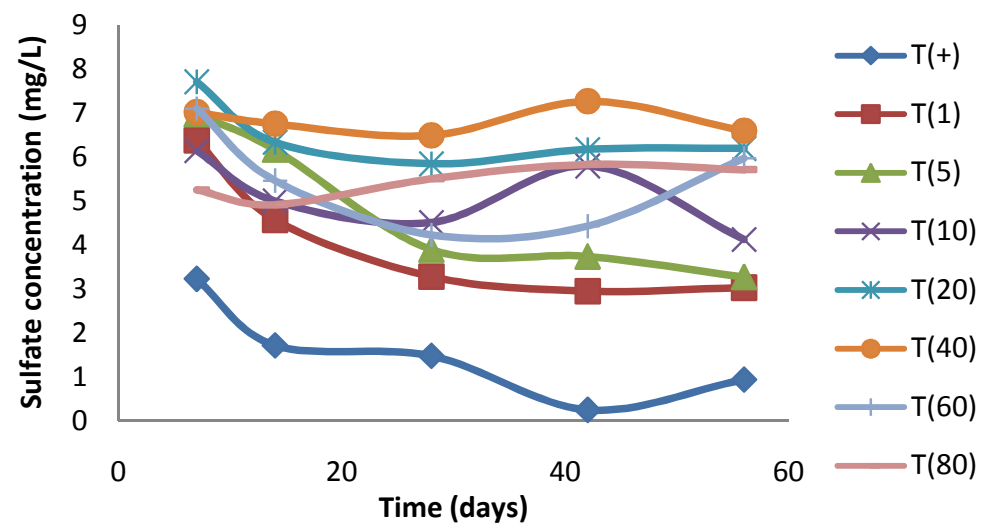

Note: $\mathrm{T}(-)=$ without $\mathrm{SRB}$ consortium; $\mathrm{T}(+)=\mathrm{SRB}$ consortium; $\mathrm{T}(1)=\mathrm{SRB}+1 \mathrm{mM}$ $\mathrm{NaNO}_{3} ; \mathrm{T}(5)=\mathrm{SRB}+5 \mathrm{mM} \mathrm{NaNO}_{3} ; \mathrm{T}(10)=\mathrm{SRB}+10 \mathrm{mM} \mathrm{NaNO}_{3} ; \mathrm{T}(20)=$ $\mathrm{SRB}+20 \mathrm{mM} \mathrm{NaNO}_{3} ; \mathrm{T}(40)=\mathrm{SRB}+40 \mathrm{mM} \mathrm{NaNO}_{3} ; \mathrm{T}(60)=\mathrm{SRB}+60 \mathrm{mM}$ $\mathrm{NaNO}_{3} ; \mathrm{T}(80)=\mathrm{SRB}+80 \mathrm{mM} \mathrm{NaNO}$

Gambar 6 Perubahan beberapa parameter pada media perendaman logam ST37: (a) pertumbuhan SRB; (b) $\mathrm{pH}$ media; and (c) konsentrasi sulfat.

Figure 6. Changes in several parameter on immersion medium of ST37: (a) Growth of SRB; (b) pH medium; and (c) sulfate concentration.

\section{Pembahasan}

Mikroorganisme pada air waduk Saguling yang tercemar diindikasikan sebagai sumber utama penyebab terjadinya korosi, terutama pada pipa di sistem pendingin. Hal ini membutuhkan biaya pemeliharaan yang sangat tinggi. Bakteri pereduksi sulfat merupakan salah satu bakteri yang paling terkenal menyebabkan korosi. Kondisi lingkungan seperti komposisi senyawa kimia yang terkandung di dalam air akan mempengaruhi pertumbuhan mikro organisme 
dan menentukan jenis mikro organisme yang dapat tumbuh. Suhu, $\mathrm{pH}$, dan ketersediaan oksigen merupakan parameter fisik yang paling menentukan jenis bakteri yang dapat tumbuh di suatu lingkungan. Kandungan beban BOD yang tinggi mengganggu kualitas air karena menyebabkan konsentrasi DO menjadi rendah. Kondisi DO yang rendah memberikan kondisi yang selektif bagi pertumbuhan bakteri. Kandungan oksigen yang terbatas memungkinkan pertumbuhan bakteri fakultatif anaerob untuk tumbuh lebih baik dibanding bakteri aerob. Kondisi ini juga mendukung pertumbuhan mikro organisme pada biofilm. Beberapa bakteri pereduksi sulfat juga diketahui mampu menghasilkan eksopolisakarida untuk pembentukan biofilm, seperti Citrobacter sp. dari kelompok Enterobacteriaceae (Shahryari et al., 2019). Pembentukan biofilm juga dipengaruhi oleh tingginya kandungan senyawa organik dan anorganik di dalam air. Konsorsium bakteri pereduksi sulfat yang diisolasi dari sampel biofilm diprediksi tidak hanya mengandung bakteri pereduksi sulfat saja, melainkan bakteri anaerob lainnya, terutama bakteri pereduksi nitrat, karena medium API Sulfat bukan medium selektif dan tidak mengandung senyawa yang dapat menghambat pertumbuhan bakteri lain. Hal ini ditandai dengan pertumbuhan koloni bakteri berwarna putih berukuran kecil pada dasar media API sulfat padat di cawan petri.

Pada uji biokorosi, penggunaan nitrat untuk menghambat aktivitas bakteri pereduksi sulfat tidak berpengaruh terhadap laju korosi logam tahan karat SUS304L karena memberikan hasil yang tidak berbeda nyata $(\mathrm{P}>0,05)$ dengan perlakuan tanpa nitrat. Hasil ini mungkin disebabkan karena logam SUS304L merupakan stainless steel yaitu logam campuran besi yang ditambahkan 10,5\% kromium atau lebih untuk memberikan ketahanan terhadap korosi. Stainless steel memiliki kemampuan tahan karat dikarenakan adanya lapisan chromium-oxide yang terbentuk dengan sendirinya ketika stainless steel mengalami kontak dengan udara yang mengandung oksigen (Duan et al., 2016). Terbentuknya lapisan film protektif ini secara tidak langsung melindungi logam dari korosi terutama yang disebabkan oleh asam sulfida $\left(\mathrm{H}_{2} \mathrm{~S}\right)$. Selain itu, masa perlakuan yang kurang lama juga diprediksi menyebabkan hasil korosi yang tidak terlihat. Moreno et al. (2014) menunjukkan adanya korosi sumuran dan biofilm yang terbentuk pada logam SUS304L dengan masa perlakuan 81 minggu, sedangkan Javed et al. (2017) menguji laju korosi bakteri pereduksi sulfat terhadap 10 jenis logam dengan masa perendaman 12 minggu.

Selama uji biokorosi pada logam ST37, penurunan jumlah bakteri pereduksi sulfat pada kontrol, yang hanya diinokulasikan konsorsium SRB saja, bukan indikasi bahwa tidak terjadi pertumbuhan bakteri pereduksi sulfat pada uji korosi kedua logam. Hal ini dikarenakan perhitungan jumlah bakteri dilakukan dengan menggunakan sampel medium, sedangkan bakteri pereduksi sulfat cenderung membentuk biofilm pada permukaan logam. Pertumbuhan bakteri pereduksi sulfat pada kontrol juga ditandai dengan penurunan $\mathrm{pH}$ dan konsentrasi sulfat yang dimanfaatkan untuk metabolism bakteri yang masih terjadi hingga akhir perlakuan. Sedangkan pada perlakuan nitrat dengan konsentrasi lebih dari $10 \mathrm{mM}$ pada uji biokorosi terhadap logam ST37 menyebabkan perubahan jumlah bakteri pereduksi sulfat yang fluktuatif namun memiliki kecenderungan penurunan jumlah bakteri selama masa inkubasi 8 minggu. Penurunan jumlah bakteri juga diindikasikan oleh kenaikan $\mathrm{pH}$ medium dan konsentrasi sulfat yang relatif tetap. Penurunan jumlah bakteri yang menunjukkan adanya kematian sel juga ditandai oleh kenaikan pH medium, karena sel-sel bakteri yang mati.Di dalam sel bakteri terdapat dua makromolekul utama, yaitu protein dan asam nukleat yang mengandung nitrogen sebagai komponen esensial. Pada saat sel bakteri mati dan lisis, molekul yang mengandung nitrogen akan dikeluarkan ke lingkungan dan meningkatkan $\mathrm{pH}$ lingkungan (Madigan et al., 2014). Sisa-sisa sel bakteri yang mati juga dapat menjadi sumber nutrisi kembali bagi sel bakteri yang masih hidup. Penggunaan sumber nutrisi ini menyebabkan peningkatan kembali jumlah sel bakteri seperti pada perlakuan dengan konsentrasi nitrat $5 \mathrm{mM}$ pada minggu ketujuh dan kedelapan.

Penurunan konsentrasi sulfat menandai pertumbuhan bakteri pereduksi sulfat. Pada perlakuan penambahan nitrat, terjadi penurunan sulfat yang lebih kecil dibandingkan perlakuan kontrol tanpa penambahan nitrat yang mengindikasikan terhambatnya pertumbuhan bakteri pereduksi sulfat. Penambahan nitrat pada logam menekan pertumbuhan bakteri pereduksi sulfat sehingga tidak terjadi penurunan sulfat setelah minggu pertama sampai kedelapan pada kedua logam. Pada konsentrasi nitrat lebih dari 10 $\mathrm{mM}$ terjadi fluktuasi kadar sulfat. Hal ini dimungkinkan merupakan indikasi adanya aktivitas bakteri pereduksi nitrat-pengoksidasi sulfida (NR-SOB) yang mampu mengubah sulfida menjadi bentuk sulfat kembali dan menekan pertumbuhan bakteri pereduksi sulfat dengan 
menghambat kerja enzim dissimilatory sulphite reductase (dsr) (Greene et al., 2003). Dibandingkan dengan penggunaan biosida yang bersifat toksik tidak hanya kepada bakteri pereduksi sulfat, penggunaan nitrat relatif aman karena menghambat pertumbuhan SRB dengan memicu pertumbuhan bakteri pereduksi nitrat. Selain koloni hitam bakteri pereduksi sulfat, pada medium API sulfat padat juga terlihat adanya pertumbuhan bakteri lain yang membentuk koloni bakteri berwana kuning dan putih pada dasar cawan petri. Bakteri yang tumbuh pada medium API sulfat ini diduga sebagai bakteri pereduksi nitrat, karena jumlah koloni yang relatif banyak pada perlakuan dengan nitrat.Secara kualitatif, pengamatan kasar menunjukkan bahwa jumlah bakteri ini cenderung lebih banyak ketika bakteri pereduksi sulfat berada dalam jumlah yang sedikit yaitu sekitar $10^{2} \mathrm{CFU} / \mathrm{mL}$.

Perubahan komunitas bakteri pereduksi sulfat selama masa perlakuan dianalisis dengan menggunakan gen $d s r B$. Gen $d s r B$ merupakan fragmen DNA mengkode subunit $\beta$ dari enzim dissimilatory sulfite reductase $\mathrm{dsr} \mathrm{AB}$. Kemampuan bakteri pereduksi sulfat menyebabkan korosi difasilitasi oleh adanya enzim $d s r A B$ tersebut, yang berperan mengkatalisis proses terakhir pada reduksi sulfat, yaitu reduksi enam elektron pada sulfat menjadi senyawa sulfida (Müller et al., 2015). Gen fungsional $d s r A B$ juga dapat digunakan untuk mengkarakterisasi bakteri pereduksi sulfat karena memiliki daerah yang lestari pada urutan sekuensnya. Berdasarkan analisis gen $d s r B$ tersebut, diketahui bahwa konsorsium bakteri pereduksi sulfat yang berhasil diisolasi mengandung 12 pita atau OTU. Perbedaan jumlah pita terjadi pada profil konsorsium bakteri pereduksi sulfat yang digunakan pada kontrol analisa perubahan komunitas bakteri, dimana profil DGGE K1 menunjukkan 13 pita DNA yaitu adanya satu pita DNA yang muncul diatas pita DNA A10, yaitu pita A13. Pita DNA A13 ini juga muncul pada beberapa sampel uji. Hal ini mungkin terjadi karena adanya bias pada proses PCR yang terjadi secara acak (random), sehingga mungkin saja ada beberapa sekuens DNA yang tidak teramplifikasi. Selain itu, Penggunaan gen $d s r B$ juga diketahui menghasilkan multiple band pada beberapa spesies bakteri pereduksi sulfat yaitu terdapat spesies bakteri yang menghasilkan lebih dari satu pita DNA pada profil DGGE. Desulfovibrio desulfuricans dan Desulfotomaculum acetoxidans merupakan contoh bakteri pereduksi sulfat yang menghasilkan multiple band. Oleh karenanya, ada kemungkinan pita DNA A13 merupakan multiple band dengan pita 82
DNA A10. Sehingga pita A13 ini tidak dianggap sebagai 1 spesies bakteri yang berbeda karena kemunculannya yang tidak selalu ada pada setiap pengulangan DGGE.

Profil DGGE menunjukkan bahwa penggunaan nitrat menyebabkan hilangnya beberapa spesies bakteri pereduksi sulfat. Terhambatnya bakteri pereduksi sulfat tidak dilakukan secara langsung oleh senyawa nitrat. Nitrat terlebih dahulu digunakan oleh bakteri pereduksi nitrat dengan mengubah senyawa nitrat menjadi nitrit (Marietou, 2016). Senyawa nitrit sebagai senyawa perantara dalam proses reduksi nitrat merupakan senyawa yang dapat menghambat proses reduksi sulfat menjadi sulfida, sehingga menekan populasi SRB. Profil DGGE (Gambar 5) menunjukkan pita DNA A3 dan A10 yang selalu ada dalam setiap paparan nitrat pada berbagai konsentrasi serta A1 dan A5 yang muncul pada konsentrasi nitrat yang tinggi, mengindikasikan kemampuan bakteri pereduksi sulfat tersebut yang mampu bertahan dari senyawa intermediet nitrit. Bakteri pereduksi sulfat dari spesies Desulfovibrio desulfuricans merupakan salah satu SRB yang memiliki aktivitas nitrite reductase dan dapat mengubah senyawa nitrit menjadi ammonium dengan adanya enzim periplasmic cytochrome c nitrite reductase (NrfHA). Kehadiran nitrit reduktase memungkinkan bakteri pereduksi sulfat untuk bertahan hidup di lingkungan yang mengandung nitrit dalam konsentrasi millimolar (Marietou, 2016).

\section{Kesimpulan}

Konsorsium bakteri pereduksi sulfat mampu menyebabkan korosi yang lebih tinggi pada logam ST37 dibandingkan logam SUS304L. Penggunaan nitrat dapat menghambat laju korosi logam baja karbon ST37 pada konsentrasi minimum $10 \mathrm{mM}$. Profil DGGE menunjukkan adanya beberapa jenis bakteri pereduksi sulfat yang terhambat pertumbuhannya, namun diperlukan analisis lebih lanjut untuk mengetahui jenis bakteri tersebut.

\section{Persantunan}

Penulis mengucapkan banyak terima kasih kepada Dr. Keukeu Kaniawati Rosada atas bantuan, diskusi dan sarannya selama melaksanakan penelitian ini. 


\section{Kontribusi}

Nur Fitriah Afianti dan Dea Indriani Astuti berperan sebagai kontributor utama dalam artikel ini.

\section{Daftar Pustaka}

ASTM. (2011). Standard Practice for Preparing, Cleaning, and Evaluating Corrosion Test Specimens. In ASTM Int., ASTM Handbook. ASTM International, West Conshohocken, PA.

Creste, S., Tulmann Neto, A., \& Figueira, A. (2001). Detection of Single Sequence Repeat Polymorphisms in Denaturing Polyacrylamide Sequencing Gels by Silver Staining. Plant Molecular Biology Reporter, $\quad 19, \quad 299-306$. https://doi.org/10.1007/BF02772828

Duan, Z., Arjmand, F., Zhang, L., \& Abe, H. (2016). Investigation of the corrosion behavior of $304 \mathrm{~L}$ and $316 \mathrm{~L}$ stainless steels at high-temperature borated and lithiated water. Journal of Nuclear Science and Technology, 53(9), 1435-1446. https://doi.org/10.1080/00223131.2015.112 5311

Enning, D., \& Garrelfs, J. (2014). Corrosion of iron by sulfate-reducing bacteria: New views of an old problem. Applied and Environmental Microbiology, 80(4), 12261236. https://doi.org/10.1128/AEM.0284813

Garno, Y. S. (2001). Status dan Karakteristik Pencemaran di Waduk Kaskade Citarum. Jurnal Teknologi Lingkungan, 2(2), 207213.

Geets, J., Borremans, B., Diels, L., Springael, D., Vangronsveld, J., van der Lelie, D., \& Vanbroekhoven, K. (2006). DsrB genebased DGGE for community and diversity surveys of sulfate-reducing bacteria. Journal of Microbiological Methods, 66(2), 194-205.

https://doi.org/10.1016/j.mimet.2005.11.00 2

Greene, E. A., Hubert, C., Nemati, M., Jenneman, G. E., \& Voordouw, G. (2003). Nitrite reductase activity of sulphate-reducing bacteria prevents their inhibition by nitratereducing, sulphide-oxidizing bacteria. Environmental Microbiology, 5(7), 607$617 . \quad$ https://doi.org/10.1046/j.14622920.2003.00446.x

Hinoue, M., Fukuda, K., Wan, Y., Yamauchi, K., Ogawa, H., \& Taniguchi, H. (2004). An
Effective Method for Extracting DNA from Contaminated Soil Due to Industrial Waste. Journal of UOEH, 26(1), 13-21. https://doi.org/10.7888/juoeh.26.13

Javed, M. A., Neil, W. C., McAdam, G., \& Wade, S. A. (2017). Effect of sulphate-reducing bacteria on the microbiologically influenced corrosion of ten different metals using constant test conditions. International Biodeterioration and Biodegradation, 125, 73-85.

https://doi.org/10.1016/j.ibiod.2017.08.011

Little, B. J., \& Lee, J. S. (2014). Microbiologically influenced corrosion: An update. International Materials Reviews, 59(7), 384-393. https://doi.org/10.1179/1743280414Y.0000 000035

Machuca, L. L. (2019). Understanding and addressing Microbiologically Influenced Corrosion (MIC). Corrosion \& Materials, 44(1), 88-96.

Madigan, M., Martinko, J., Bender, K., Buckley, D., \& Stahl, D. (2014). Brock Biology of Microorganisms, 14th Edition. In Igarss 2014.

Marietou, A. (2016). Nitrate reduction in sulfatereducing bacteria. FEMS Microbiology Letters, 363(15), fnw155. https://doi.org/10.1093/femsle/fnw155

McCaig, A. E., Glover, L. A., \& Prosser, J. I. (2001). Numerical Analysis of Grassland Bacterial Community Structure under Different Land Management Regimens by Using 16S Ribosomal DNA Sequence Data and Denaturing Gradient Gel Electrophoresis Banding Patterns. Applied and Environmental Microbiology, 67(10), 4554-4559.

https://doi.org/10.1128/AEM.67.10.45544559.2001

Moreno, D. A., Ibars, J. R., Polo, J. L., \& Bastidas, J. M. (2014). EIS monitoring study of the early microbiologically influenced corrosion of AISI 304L stainless steel condenser tubes in freshwater. Journal of Solid State Electrochemistry, 18, 377388. https://doi.org/10.1007/s10008-0142390-6

Müller, A. L., Kjeldsen, K. U., Rattei, T., Pester, M., \& Loy, A. (2015). Phylogenetic and environmental diversity of DsrAB-type dissimilatory (bi)sulfite reductases. ISME Journal, 9, 1152-1165. https://doi.org/10.1038/ismej.2014.208

Priha, O., Nyyssönen, M., Bomberg, M., Laitila, A., Simell, J., Kapanen, A., \& Juvonena, R. 
(2013). Application of denaturing highperformance liquid chromatography for monitoring sulfate-reducing bacteria in oil fields. Applied and Environmental Microbiology, 79(17), 5186-5196. https://doi.org/10.1128/AEM.01015-13

Putra, A. W., \& Hasan, Z. (2012). Struktur komunitas plankton di sungai Citarum Hulu Jawa Barat. Jurnal Perikanan Dan Kelautan, 3(4), 313-325. http://jurnal.unpad.ac.id/jpk/article/view/25 76

Rosada, K. K., Afianti, N. F., Astuti, D. I., Suantika, G., \& Aditiawati, P. (2014). Bacterial community structures of planktoic cells and biofilm at Saguling hydro power using denaturing gradient gel electrophoresis (DGGE). Journal of Biological Sciences, 14(6), 414-424. https://doi.org/10.3923/jbs.2014.414.424

Rosada, K. K., Najia, N., Ningrum, R. W., Astuti, D. I., Suantika, G.,\& Aditiawati, P. (2017). The ability of biofilm community sampled from metal surfaces at Saguling hydro power in utilizing carbon sources by using biolog ecoplate ${ }^{\mathrm{TM}}$. Journal of Biological
Sciences,

$17(1)$ $11-20$.

https://doi.org/10.3923/jbs.2017.11.20

Shahryari, Z., Gheisari, K., \& Motamedi, H. (2019). Effect of sulfate reducing Citrobacter sp. strain on the corrosion behavior of API X70 microalloyed pipeline steel. Materials Chemistry and Physics, 236, https://doi.org/10.1016/j.matchemphys.201 9.121799

Venzlaff, H., Enning, D., Srinivasan, J., Mayrhofer, K. J. J., Hassel, A. W., Widdel, F., \& Stratmann, M. (2013). Accelerated cathodic reaction in microbial corrosion of iron due to direct electron uptake by sulfate-reducing bacteria. Corrosion Science, 66, 88-96. https://doi.org/10.1016/j.corsci.2012.09.006

Zhang, Y., Wang, X., Zhen, Y., Mi, T., He, H., \& $\mathrm{Yu}$, Z. (2017). Microbial diversity and community structure of sulfate-reducing and sulfur-oxidizing bacteria in sediment cores from the East China Sea. Frontiers in Microbiology, 8 , 2133. https://doi.org/10.3389/fmicb.2017.02133 